\title{
BIOANTHROPOLOGICAL ANALYSIS OF THE MEDIEVAL POPULATION FROM VINČA - BELO BRDO: PRELIMINARY RESULTS
}

\author{
Veda Nikolić \\ Laboratory for Anthropology, Faculty of Medicine, University of Belgrade \\ Ksenija Đukić \\ Laboratory for Anthropology, Faculty of Medicine, University of Belgrade \\ Kristina Penezić \\ BioSense Institute, University of Novi Sad \\ e-mail: vdnikolic@gmail.com $\mid$ Preliminary article \\ Received: 10. 5. 2021. UDC: 904:572.781.08(497.11)"2004/2020" \\ Accepted: 9. 6. 2021. 904:726.821"653"(497.11)
}

\begin{abstract}
The paper presents the preliminary results of the bioanthropological analysis of the human osteological material from the medieval necropolis of Vinča - Belo Brdo, preliminarily dated into the period from the late $12^{\text {th }}$ to the early $14^{\text {th }}$ century. The bioanthropological analysis was carried out at the Laboratory for Anthropology, Faculty of Medicine. A total of 117 individuals from 68 graves were observed, of which 27 were female, 22 male, while 36 were subadults. In total, the sex of 32 individuals could not be determined due to poor or incomplete preservation of skeletal remains. The analysis of paleopathological conditions of observed individuals showed that most of them suffered from degenerative changes of the skeletal joint system. Skull and long bone traumas were also noted, as well as signs of porosity, indicating nutritional deficit and possibility of phases of anaemic stress.
\end{abstract}

Keywords: Vinča - Belo Brdo, medieval necropolis, paleodemographic and paleopathological analyses, dental disease, subadult stress, enthesal changes

\section{Introduction}

After a few decades' hiatus, excavations of the medieval necropolis were resumed on the site of Vinča - Belo Brdo, during the campaigns of 2004, 2005 and 2011. The decision to continue the excavation of the necropolis was mainly conditioned by the landslides on the site which caused the need to protect this part of it, and prevent the loss of valuable information. During these campaigns, over 70 graves were excavated, and anthropologically analysed.

Considering the low representation of bioanthropological material dating from the medieval period that is analysed or published, and that there are not enough written sources about the everyday life of people in this period, the 
analysis of the Vinča necropolis would contribute to a better understanding of the way of life and the health status of the medieval communities in Serbia. The mentioned necropolis has been researched for several decades and the analyses of bioanthropological material have been performed in phases, consequently, the obtained results will be the basis of further comparative analyses. A more comprehensive picture of the health status of the buried population and its distribution by sex, age and specific diseases will be obtained.

Based on the data provided from the literature, it is has been concluded that the predominant type of settlement in Serbia was that of a rural character, and its inhabitants were mainly engaged in agriculture (Marković, Bulatović, 2013) and, to a lesser extent, animal husbandry, as evidenced by the archaeozoological material (Blažić, 1999a, б; Булатовић, Марковић, 2013; Mladenović, 2017; Булатовић, Марковић, 2019). According to some researchers, there were several rural settlements in the immediate vicinity of the medieval necropolis of Vinča - Belo Brdo (Марјановић-Вујовић, 1984; Калић, 1995; Милошевић, 1997; Фидановски, Зечевић, 2015), therefore, we can assume that, due to inadequate living conditions and limited resources, the individuals buried in this necropolis most likely had poor health status, which has so far been proven through bioanthropological analysis performed on a sample of 50 skulls from the same necropolis (Марковић, Јовановић, 2019). However, it should be noted that the anthropological analysis was done on only 50 skulls, out of 713 graves excavated in the 1978-1983 campaign. The remaining skeletal remains were not analysed, but buried on the site instead. Furthermore, the choice criteria are not known for the sample of 50 skulls, whether it was a random sample or if only the skulls showing pathological changes were saved. In any case, this is just a small part of a larger sample, which makes the conclusion about the bad health status unreliable.

The aim of this paper is to help create a more complete picture about the health status and quality of life for the medieval population and to enable further comparative analyses. Considering that the medieval necropolis is not completely excavated and that work continues, this paper will provide data about paleodemographic and pathological characteristics of the buried population which can later be added to further studies of the osteological material from the site of Vinča - Belo Brdo.

\section{The site of Vinča - Belo Brdo}

The site of Vinča - Belo Brdo is located ca. 14 km south-east of Belgrade, on the right bank of the Danube. During more than a century of excavations, with minor or major interruptions, a cultural layer was found, up to $10 \mathrm{~m}$ thick, dating from the Early Neolithic, through the Bronze Age to the Middle 
Age. At the top of the site, on the remains of material culture from the prehistoric period, there is a large medieval necropolis, still unexplored in its entirety.

The research of the medieval necropolis, carried out by G. Marjanović -Vujović, was the most extensive, from 1978 to 1983. During this period, 713 graves were excavated, dated from the $8^{\text {th }}$ to the $17^{\text {th }}$ century, classified into four horizons, on the basis of grave goods discovered during excavations in campaigns 1911-1912 (led by M. Vasić) and 1978-1983, or those obtained through purchase (Марјановић-Вујовић, 1984; Тасић, 2008; Пенезић et al., 2020). Based on the field documentation from 1978-1983, it was established that the last horizon $\left(16^{\text {th }}-17^{\text {th }}\right.$ century) was singled out only on the basis of finds from the museum collection. Reports from the excavations of G. Marjanović-Vujović indicate to us that only the central part of the cemetery was explored, and its edges and its precise area have not been clearly defined yet.

The excavations of the medieval necropolis continued in 2011, in the part of the site under immediate threat of landslides. A trench was opened in 2011, measuring about 4 × $20 \mathrm{~m}$, located a few metres from Vasićs excavation of $1930^{1}$ (Fig. 1). A total of 71 graves $^{2}$, of varying degrees of preservation, were discovered and excavated. The preservation of skeletons and graves depended primarily on the long-term use of the burial area, as a result of which more recent graves often devastated older burials. Individuals were buried in rectangular, earthen graves, without any grave architecture, probably in wooden coffins, oriented along the west-east axis, with slight deviations. They were buried in an extended position, supine, with their hands mostly resting on their torso or crossed on their chests. Most of the graves contained one skeleton, but because of the long-term use of the burial space, skeletal remains were mixed and in most of the graves there was more than one individual. Grave goods were rare and in the form of earrings, rings and diadems.

The research of the medieval necropolis of Vinča - Belo Brdo continued in 2019, and had a protective character. The trench from 2011 was expanded during the excavations. Based on a small number of grave goods and analogies, this part (excavations from 2011 and 2019) is dated into the period from the late $12^{\text {th }}$ to the early $14^{\text {th }}$ century (Пенезић et al., 2020).

The skeletal remains excavated during the first major campaign (19781983) were bioanthropologically analysed by Ž. Mikić (Микић, 1988), after

\footnotetext{
${ }^{1}$ In this zone, before and after terrain movements caused by landslide, near the edges of the excavation, east of the 2011 trench, smaller excavations were made in 2004, 2005 as well as in 2012-2014. Our bioanthropological analysis covers skeletons from 2004 and 2005.

${ }^{2}$ Other than these, multiple individual units were excavated without numbered graves, with large concentrations of human bones, four of which were included in this analysis.
} 


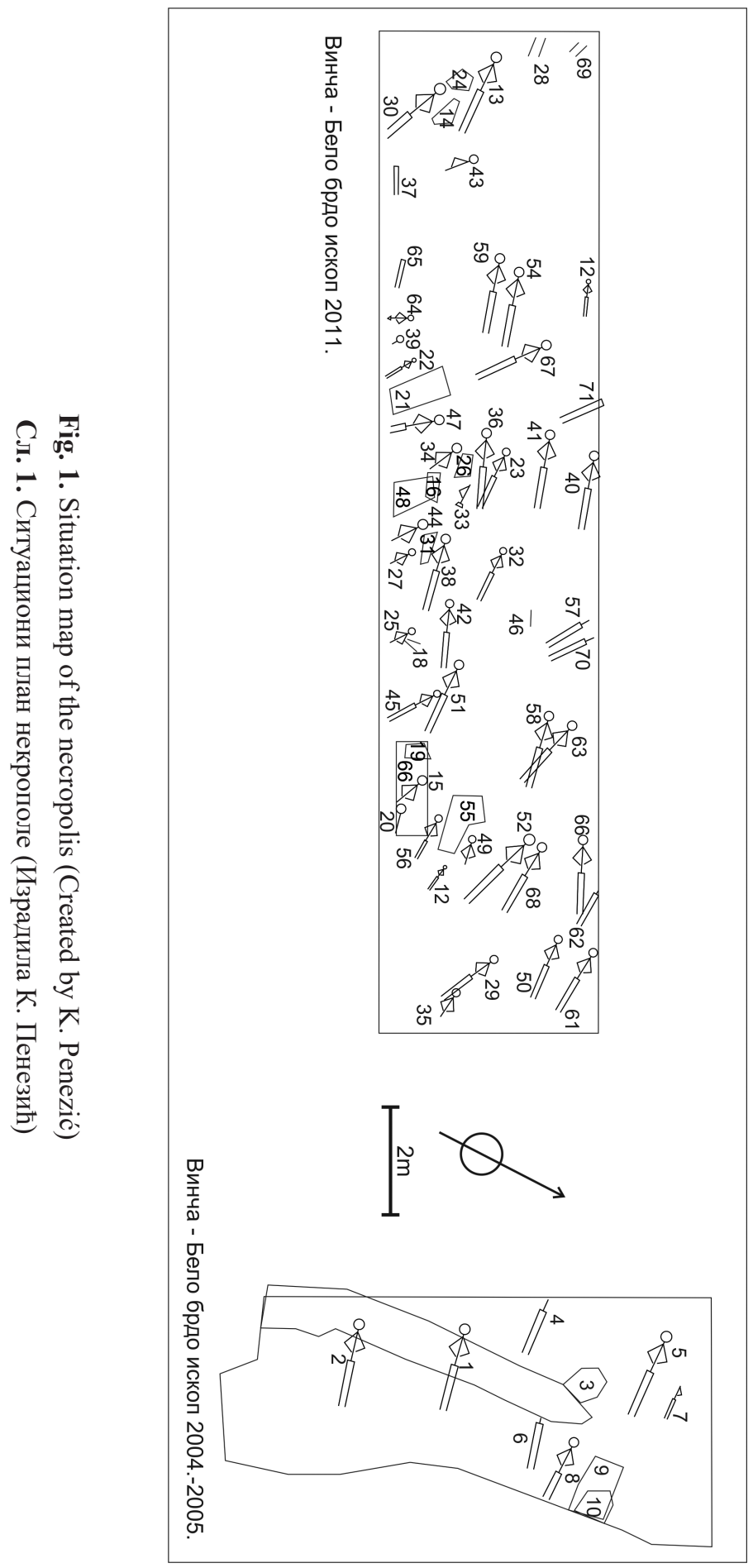


which the skeletons were re-buried on the site, while 50 skulls from these excavations were stored and maintained in the Paleopathological Collection of the Faculty of Philosophy, in Belgrade. The mentioned skulls were first analysed by Ž. Mikić, and then I. Mikić, who dealt with the issue of their epigenetic characteristics, after which J. Marković and J. Jovanović investigated the issue of the health status and nutrition of the buried individuals (Микић, 1988; Mikić, 2009, Марковић, Јовановић, 2019). In addition to this, the analysis of the entheses at the level of bone microarchitecture was performed by K. Đukić (Đukić et al., 2015; Đukić, 2016).

\section{Material and methods}

The bioanthropological analysis of the human osteological material was carried out at the Laboratory for Anthropology, Faculty of Medicine, in Belgrade. The analysis included determining the degree of preservation of skeletal remains, estimation of age-at-death, the determination of the individuals' sex, paleopathological and dental analyses, as well as the reconstruction of the height of the individuals. Additionally, a preliminary analysis of the morphological appearance of entheses was performed.

The analysed skeletal remains from the medieval necropolis of Vinča Belo Brdo were investigated in the campaigns of 2004, 2005 and 2011. A total of 117 individuals from 68 graves were observed.

The degree of preservation of skeletal remains was determined according to the methodology proposed by Ž. Mikić (Mikić, 1978). The individual sex and age-at-death of individuals were determined using standard bioanthropological procedure (Workshop of European Anthropologists 1980; Brothwell, 1981). The analysis of sex was based on the morphological characteristics of the skull and pelvis (Ferembach et al., 1980; Buikstra and Ubelaker, 1994), while the biological sex of children was not determined. Age-at-death was determined based on the morphological appearance of the pelvis and the sternal ends of the ribs (Ischan et al., 1984, 1985; Suchey and Brooks, 1990), as well as on degenerative changes on the major joints of the long bones and on vertebrae (Pfeiffer, 1991). Age-at-death in subadults was estimated based on the development of deciduous and permanent teeth (Ubelaker, 1984), and the degree of bone ossification and diaphyseal length of long bones were recorded (Brothwell, 1981; Maresh, 1955, 1970; Bass, 1995; Scheuer, Black, 2004).

The average height of adults was reconstructed based on the maximal length of the long bones, using the so-called Trotter-Gleser technique (Trotter and Gleser, 1958), in cases where the preservation of osteological material allowed that. 
All paleopathological changes were primarily observed macroscopically, except in susceptive cases where radiological observations were used (Schultz, 2001). The examination of paleopathological changes was mainly based on the gross examination of bones (Ortner, 2003; Buikstra, 2019).

The analysis of the dental material included determining the state of preservation, i.e. recording the number of teeth present and/or absent. In addition, a complete record of the paleopathological condition of the jaws and teeth was performed, which included recording the presence of caries and alveolar diseases (Buikstra and Ubelaker, 1994). All these parameters were observed separately, and then in a border context, since all these indicators are interrelated.

In the analysis of the paleopathological picture of the buried population, special attention was paid to noting the biological indicators of physiological stress, such as cribra orbitalia, cribra femoris, humeral cribra, enamel hypoplasia and periosteal reaction, since they can be good indicators of the quality of life and health status of buried individuals (Angel, 1966; Stuart-Macadam, 1985, 1989, 1992; Walker et al., 2009; Ortner, 2003; Djurić et al., 2008; Zarina et al., 2016; Brickley, 2018; Rinaldo et al., 2019).

Identification and recording of the enthesal changes (EC) was performed on the apendicular skeleton, observing the fibrous and fibrocartilage macromorphological appearance of 19 entheses on the upper and lower extremities (Đukić, 2016). The analysis of enthesal changes was not performed in developing individuals, i.e. in those individuals in whom the process of growing or the process of the adhesion of epiphyseal - diaphyseal joints was not completed.

\section{Results}

The bioanthropological analysis was performed on a sample of 117 individuals, from a total of 68 graves. According to field documentation, during the campaigns in 2004, 2005, and 2011, 71 graves were excavated, however, only 68 graves were available for analysis. ${ }^{3}$

After the bioanthropological analysis, it was concluded that in almost all graves, in addition to the primarily buried individual, there were also individual bones or parts of skeletons of other individuals, which additionally confirms that the necropolis was used for a longer period of time, for several generations. It should also be noted that the total number of buried individuals is not considered accurate for these reasons, as this has led to mixing of materials and partial dev-

\footnotetext{
${ }^{3}$ Seven graves were excavated during the 2004 campaign (1/04-7/04), 3 graves were excavated in 2005 campaign (8/05-10/05), while in 2011 the numeration was continued and 61 graves were excavated, as well as 4 unnumbered graves, which were also included in the analysis.
} 


\section{THE DEGREE OF SKELETAL PRESERVATION}

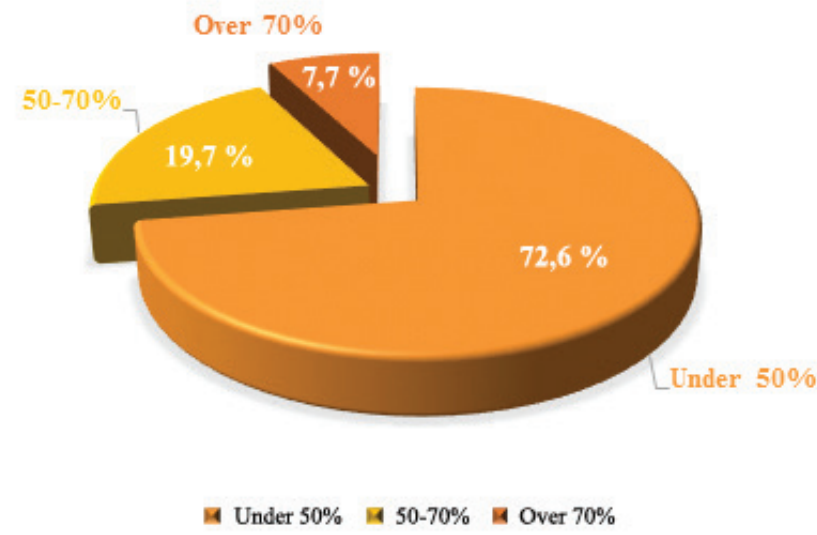

Chart 1. The degree of skeletal preservation

Графикон 1. Степен очуваности скелетних остатака

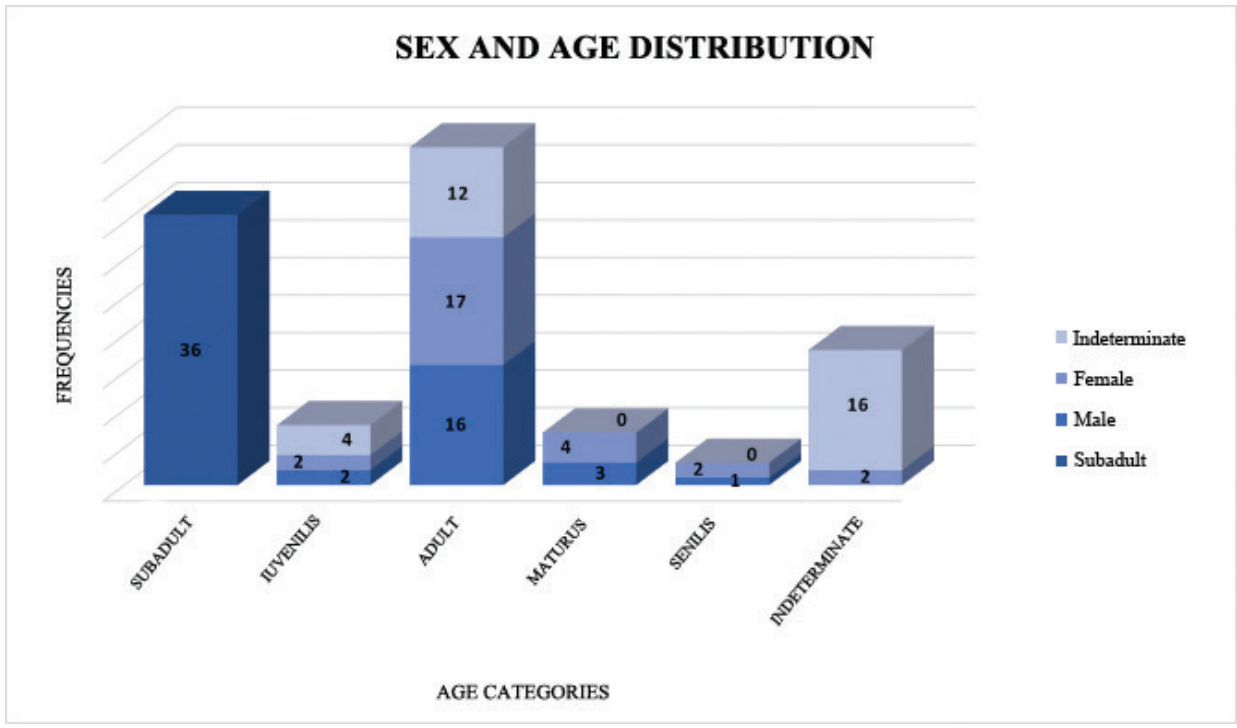

Chart 2. Sex and age distribution

Графикон 2. Дистрибуција по полу и старости 


\section{FREQUENCY OF PATHOLOGICAL CHANGES}

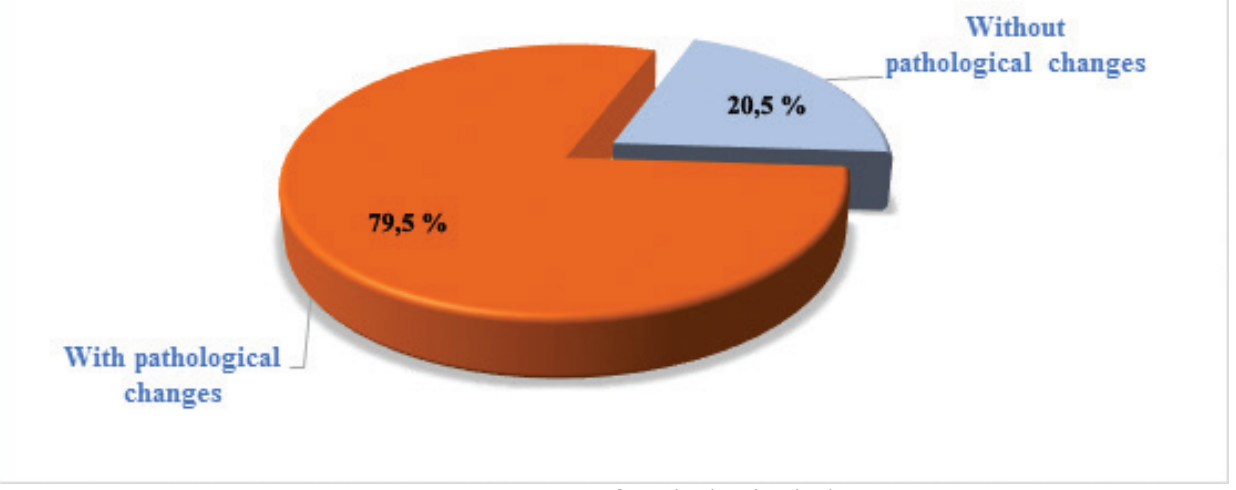

Chart 3. Frequency of pathological changes

Графикон 3. Учесталост патолошких промена

astation of the skeletal remains. For the same reasons, it is not surprising that the degree of preservation of the skeletal remains is mostly below 50\% (app. 72.6\%), except in 6 cases (graves 13/11, 38/11, 51/11, 52/11, 63/11 and 66/11) where the skeletons were preserved very well, almost completely (above 70\%) (Chart 1).

The analysis of distribution by sex and age showed that out of 117 individuals, 27 were female, 22 male and 36 were subadults, while it was not possible to accurately determine sex due to poor preservation in 32 individuals. Paleodemographic analysis of the observed individuals showed an almost uniform distribution by sex and age (Chart 2). The average age of adult individuals is about 39 years of age for females and about 34 for males, while the average age-at-death in subadult individuals is about 3.2 years. The youngest child individual was 9-9.5 weeks old.

The average reconstructed height in adults is about $157 \mathrm{~cm}(157.3 \mathrm{~cm}$ for females and $167.63 \mathrm{~cm}$ for males). In many cases, due to poor preservation, it was not possible to reconstruct the height of individuals.

The paleopathological research of osteological material from the medieval necropolis of Vinča - Belo Brdo showed a high percentage of pathological changes (79.5\%) (Chart 3). The most common form of disease are osteoarthritic changes on auricular surfaces, on superior and inferior edges on the body of vertebrae or on joint area of humerus, ulna, clavicle, scapula and pelvis. Osteoarthritic changes mostly manifested through growths (osteophytes) which can, in harder cases, cause merging of individual vertebrae into a single bone structure. Other than that, the so-called Schmorl's nodes are common on the examined sample. The highest percentage of these changes was noted on people who were able to work as a result of mechani- 


\begin{tabular}{|c|c|c|c|}
\hline \multirow{2}{*}{ Sex } & \multicolumn{2}{|c|}{ Diseases of Joints } & \multirow{2}{*}{ Total } \\
\cline { 2 - 3 } & Presence & Absence & 22 \\
\hline Male & 13 & 9 & 27 \\
Female & 15 & 12 & 36 \\
Subadult & 0 & 36 & 32 \\
Undetermined & 3 & 29 & 117 \\
\hline Total & 31 & 86 & \\
\hline
\end{tabular}

Table 1. Distribution of degenerative changes on joint surfaces according to the sex and age

Табела 1. Дистрибуција дегенеративних промена зглобних површина по полу и старости

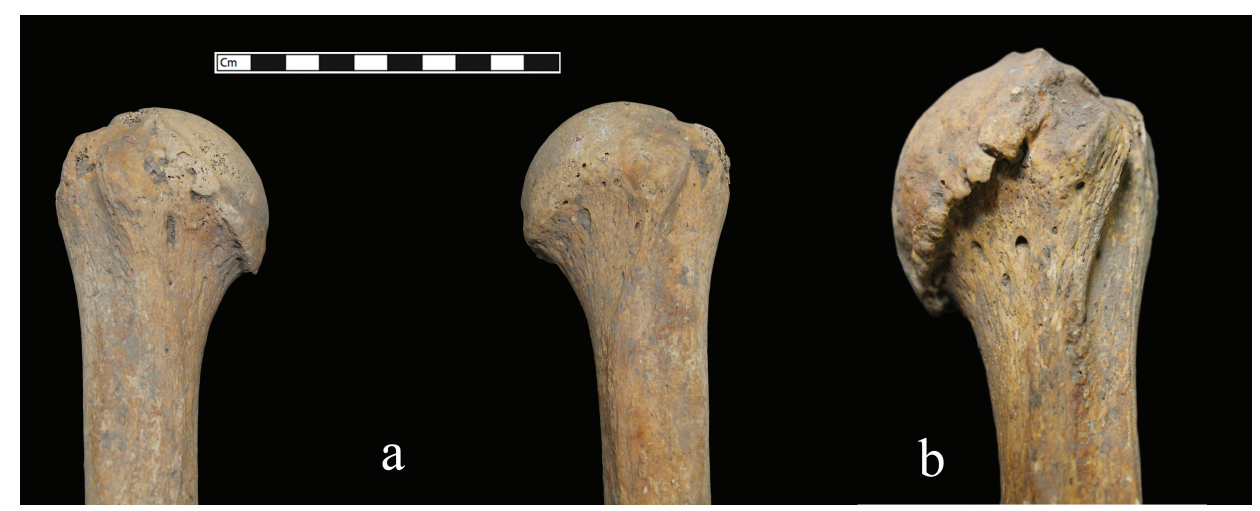

Fig. 2. Osteoarthritis on the head of humerus: a) grave 48/11, b) grave 52/11 (Photo by V. Nikolić, edited by I. Mikašinović)

Сл. 2. Остеоартритичне промене на главама хумеруса: а) гроб 48/11, б) гроб 52/11 (Фотографисала В. Николић, обрадио И. Микашиновић)

cal stress and intense physical activity (Waldron, 2009). In the case of individuals buried on the site of Vinča - Belo Brdo, osteoarthritic changes are present only in adult individuals, of middle age, and in terms of the sex distribution, it was slightly more prominent in female individuals (Table 1). For instance, in two cases (grave 48/11 and 52/11) we noticed degenerative osteoarthritis on the head of the humerus (Fig. 2). In the case of the individual buried in grave 48/11 (aged 35-45) (Fig. 2a), as a consequence of osteoarthritis, a pseudo-joint was formed on the acromion of the right scapula, probably as a result of inadequate use of the arm. Also, there are two cases with spondylosis (graves 6/04 and 47/11, as well as several cases with the appearance of osteophytes on the marginal parts of the vertebral body (Fig. 3).

In two cases, the fractures of the distal forearm were noted (graves 10/05 and 45/11) (Fig. 4). In the individual from grave 10/05 (Fig. 4a), at the distal end of 


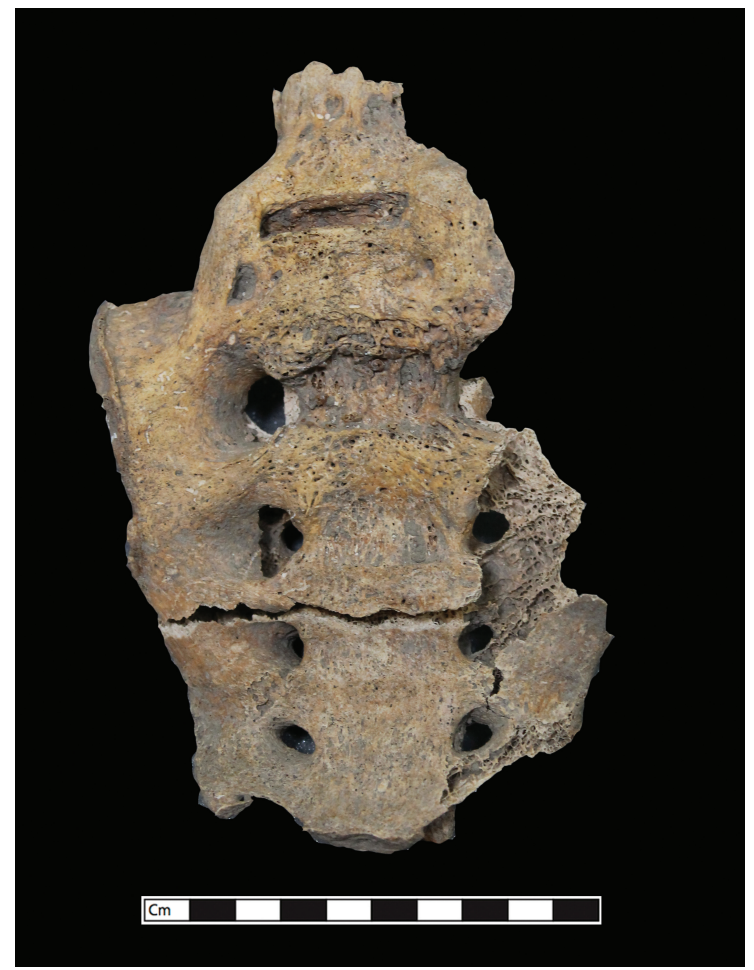

Fig. 3. Spondylosis, grave 47/11 (Photo by V. Nikolić, edited by I. Mikašinović)

Сл. 3. Спондилоза, гроб 47/11 (Фотографисала В. Николић, обрадио И. Микашиновић)

the left ulna, a spindle-shaped body was found after a life-threatening fracture. The fracture was caused by a fall on the open hand, which caused the rotation of the diaphysis of the left forearm bones (Resnick, Kransdorf, 2005; Djurić et al., 2006). On the olecranon fossa of the left humerus, a new bone was formed due to the improper healing and use of the arm after the fracture. In the second case (grave 45/11) (Fig. 4b), the loco typico fracture was found on the distal part of the right radius. On this, an angulation of the diaphysis was noted, which indicates a healed fracture and, therefore, the possibility of the existence of an extremely fused muscle attachment extensor processus longus is ruled out. At the distal end of the right radius, traces of discrete lipping can be seen. Accompanying changes, in the form of pseudo-joints, were also noticed in the middle of the diaphysis of the right ulna.

On the frontal bone of the skull of the individual buried in grave 66 (Fig. 5), an impression fracture, about $1.4 \mathrm{~cm}$ in length, was recorded in the area of the suturae metopica caused by a sharp tool or weapon. The injury was observed under the stereo Leica MS5x10, with the magnification of 6X to establish the nature of the injury. After the observation, it was determined that it was a perimortal in- 


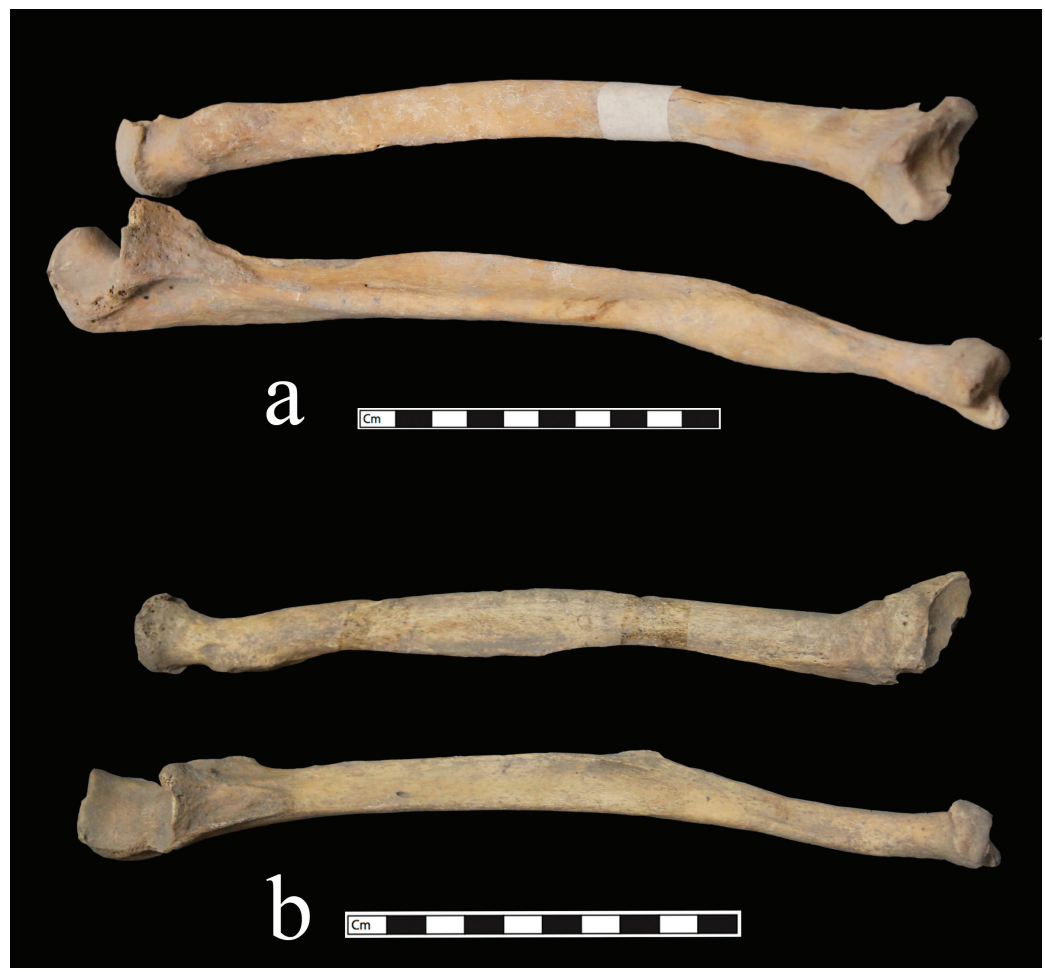

Fig. 4. Loco typico fracture: a) grave 10/05, b) grave 45/11

(Photo by V. Nikolić, edited by I. Mikašinović)

Сл. 4. Loco typico фрактура: а) гроб 10/05, б) гроб 45/11

(Фотографисала В. Николић, обрадио И. Микашиновић)

jury with traces of reparation, which indicates that the person survived the impact and lived on for some time.

When it comes to traces of infections and stress indicators, active periostitis has been recorded in only three cases: on the right tibia (grave 16/11), on the left humerus (grave 63/11) (Fig. 6) and on the skeletal remains from grave 65/11 (Fig. $7,8)$. Traces of porosity were noticed in a small percentage, mostly on the cranial skeleton, most often on the parietal and temporal bones, around the ear openings, which may be a consequence of metabolic stress suffered in childhood, defined as porous hyperostosis. In one case (grave 23/11), in an individual aged 7-9, porotic hyperostosis was noted on the lamina externa of both parietal bones (Fig. 9).

Based on the assumed number of teeth and the age of the individual, a generally poor preservation of the dental material is deduced. Due to this, it was not possible to precisely determine the percentage of teeth present or ante and post mortem tooth loss. 

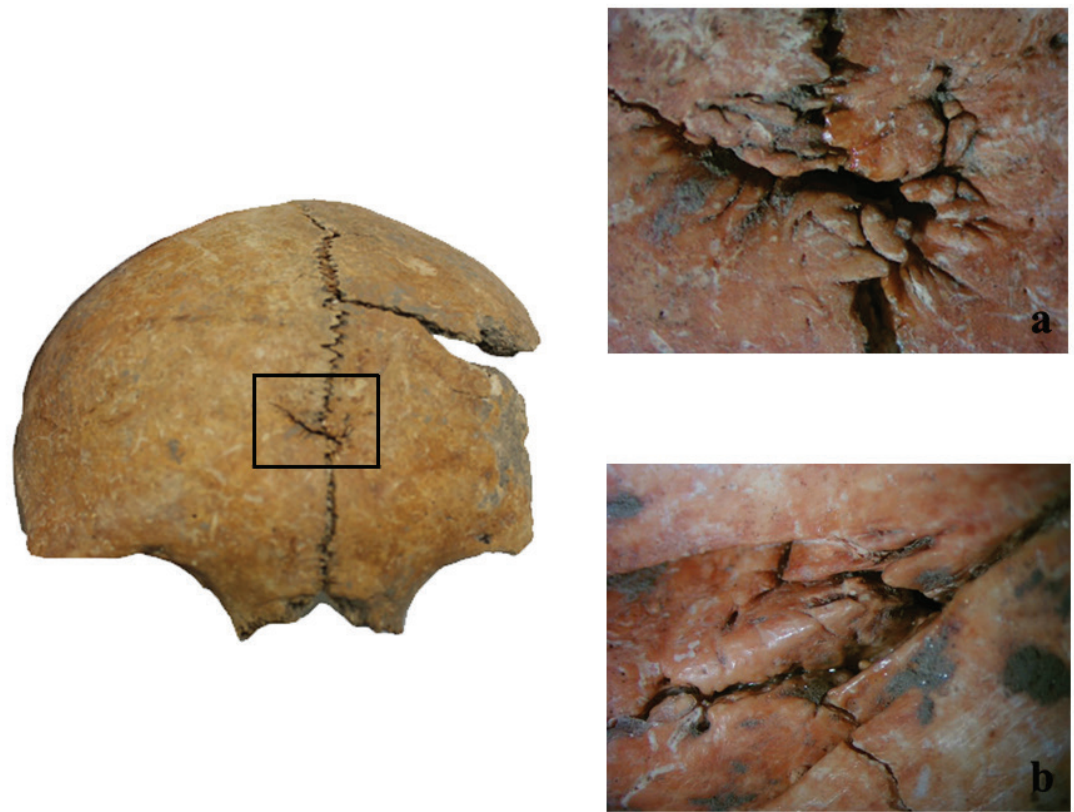

Fig. 5. Impression fracture, grave 66/11 (Photo by V. Nikolić, edited by I. Mikašinović)

Сл. 5. Импресиона фрактура, гроб 66/11 (Фотографисала В. Николић, обрадио И. Микашиновић)

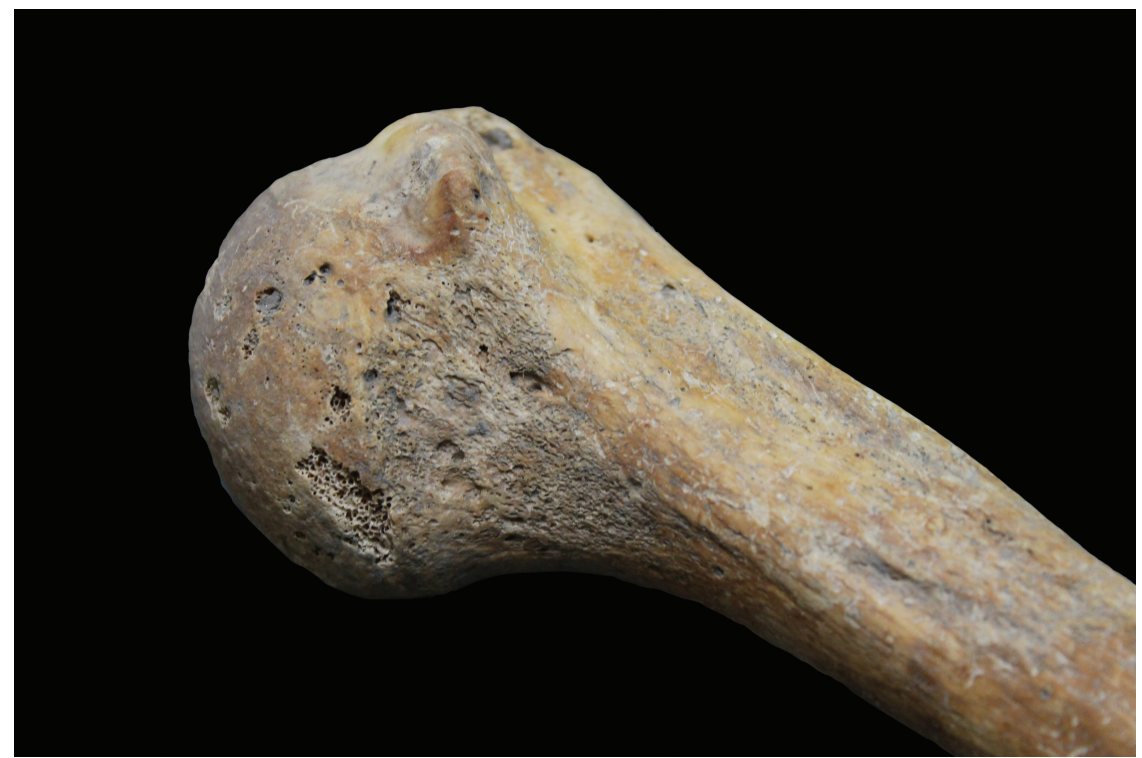

Fig. 6. Active periostitis, grave 63/11 (Photo by V. Nikolić, edited by I. Mikašinović)

Сл. 6. Активни периоститис, гроб 63/11

(Фотографисала В. Николић, обрадио И. Микашиновић) 


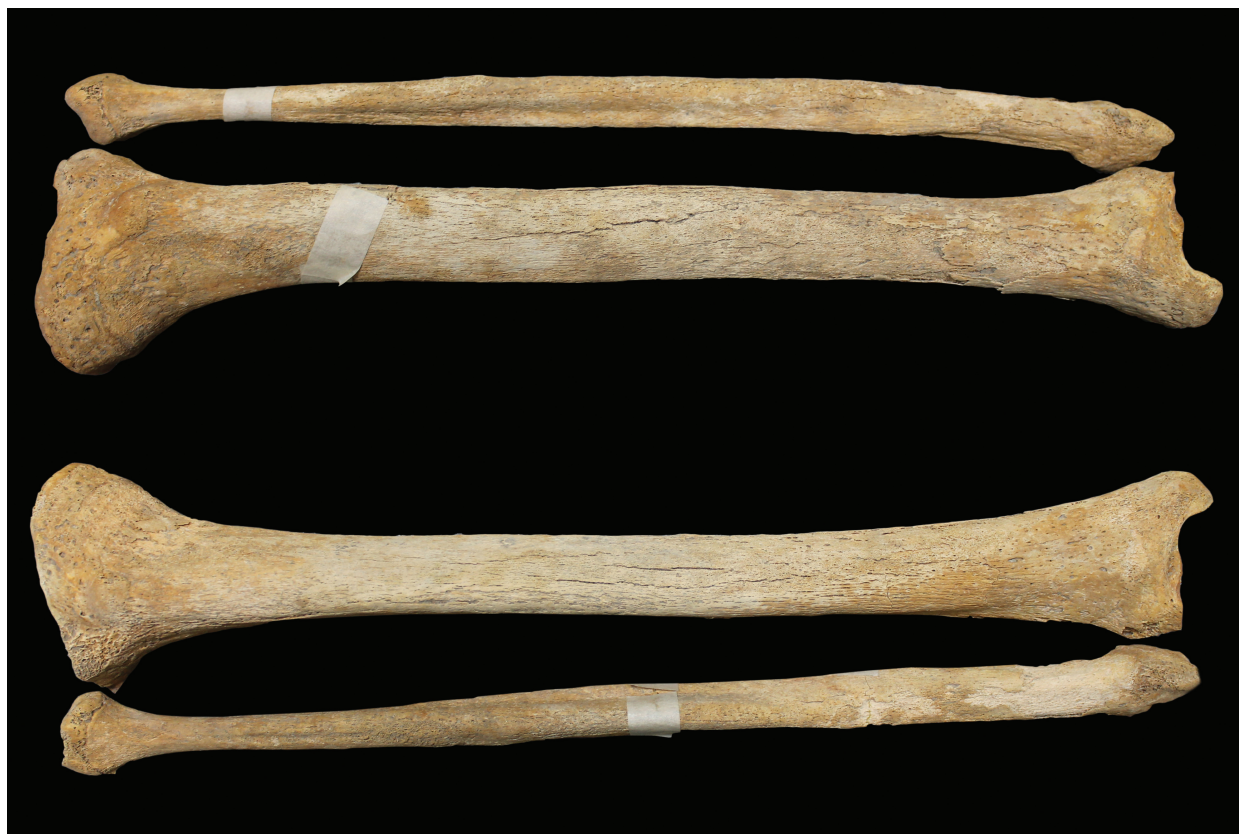

Fig. 7. Active periostitis on tibiae, grave $65 / 11$

(Photo by V. Nikolić, edited by I. Mikašinović)

Сл. 7. Активни периоститис на тибијама, гроб 65/11

(Фотографисала В. Николић, обрадио И. Микашиновић)

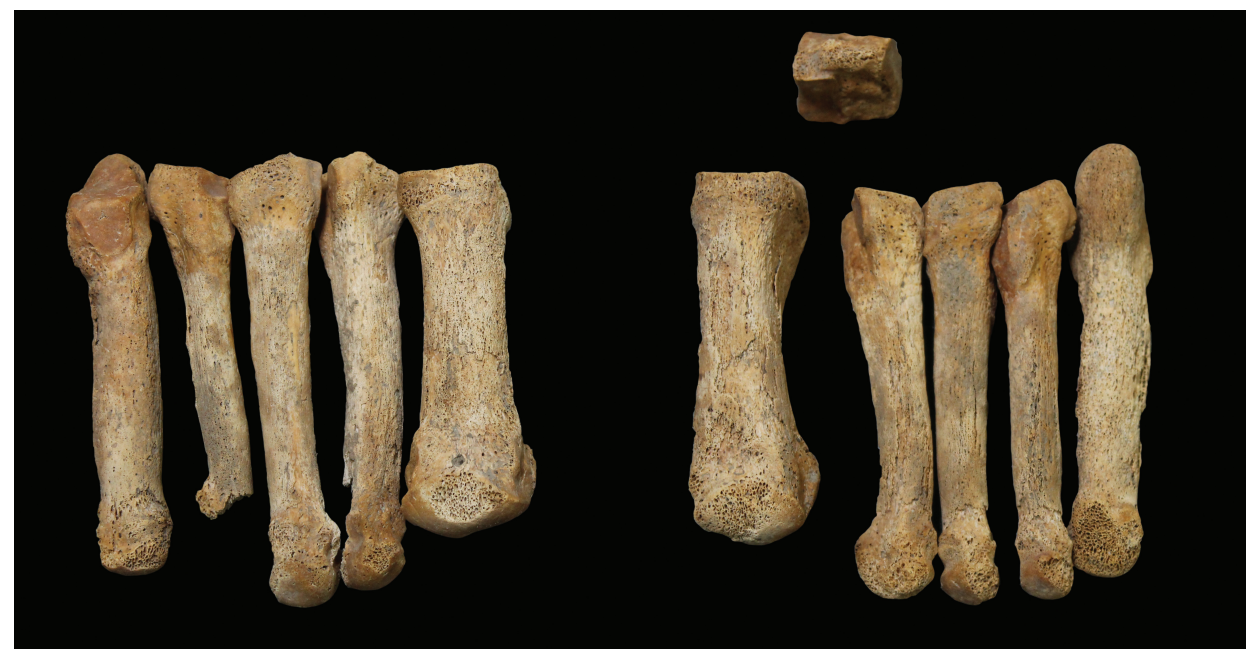

Fig. 8. Active periostitis on the foot bones, grave 65/11

(Photo by V. Nikolić, edited by I. Mikašinović)

Сл. 8. Активни периоститис на костима стопала, гроб 65/11 (Фотографисала В. Николић, обрадио И. Микашиновић) 


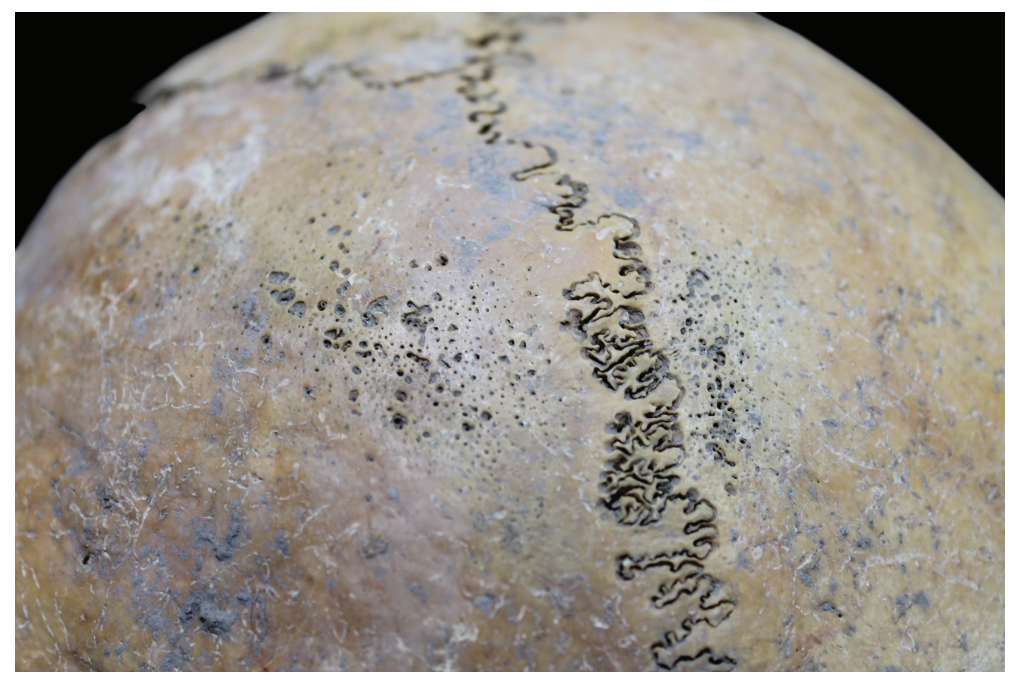

Fig. 9. Porotic hyperostosis, grave 23/11 (Photo by V. Nikolić, edited by I. Mikašinović)

Сл. 9. Поротична хиперостоза, гроб 23/11

(Фотографисала В. Николић, обрадио И. Микашиновић)

\begin{tabular}{|c|c|c|c|}
\hline \multirow{2}{*}{ Sex } & \multicolumn{2}{|c|}{ Frequency of carious lesions } & \multirow{2}{*}{ Total } \\
\cline { 2 - 3 } & Presence & Absence & 22 \\
\hline Male & 8 & 14 & 27 \\
Female & 11 & 16 & 36 \\
Subadult & 4 & 32 & 32 \\
Undetermined & 1 & 31 & 117 \\
\hline Total & 24 & 93 & \\
\hline
\end{tabular}

Table 2. Frequency of carious lesions

Табела 2. Учесталост каријесних лезија

Dental diseases are manifested through carious lesions, periodontitis and periapical processes, mostly in adults. Caries is present in only $21.2 \%$ (Table 2), while periodontitis was observed in $11.5 \%$ or a total of 13 individuals. Periapical processes probably caused by the action of bacteria from carious lesions were ascertained in 5 cases.

Tooth abrasion is weak, most often at level I or II, and is present in $27.4 \%$ of the total sample, in the largest percentage in adult individuals. In the case of the individual from grave 13/11, aged 30-46, grade III abrasion is present on the central maxillary incisors, which is one of the rarer examples. Calculus is present on almost all teeth to a greater or lesser extent, in $21.2 \%$ of cases. 


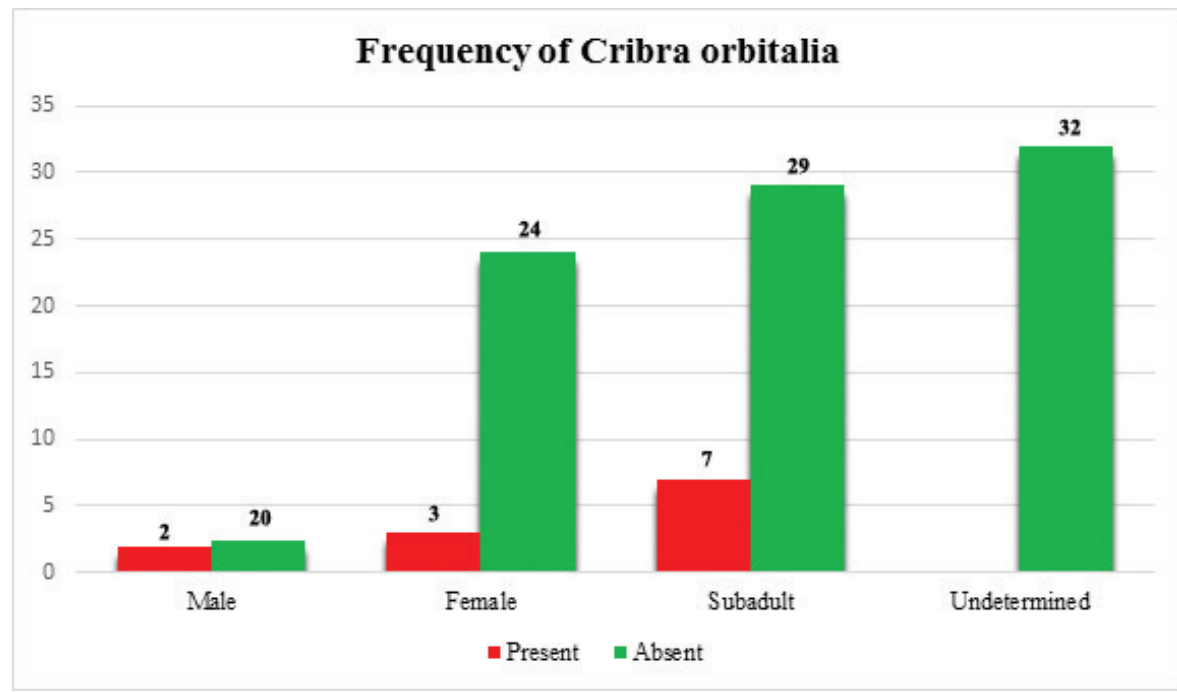

Chart 4. Frequency of cribra orbitalia

Графикон 4. Учесталост cribra orbitalia

Indicators of subadult stress, such as cribra orbitalia, cribra femoris and humeral cribra were analysed according to the methodology suggested by StuartMacadam $(1985,1989,1992)$. All the cases with traces of porosity were taken into consideration, from light to severe grade, both uni- and bilaterally. Cribra orbitalia, cribra femoris, humeral cribra and enamel hypoplasia were recorded in a relatively low percentage. More precisely, cribra orbitalia is present in a total of 12 individuals or in $10.3 \%$ of cases (Chart 4), while cribra femoris (Fig. 10a,b,c) and humeral cribra were ascertained in 21 (17.9\%) and 2 cases (1.7\%). Cribra orbitalia is observed mainly bilaterally in the lateral part of the orbital roof and is mostly manifested in the form of small and large isolated foramina or scattered fine foramina in this area (Fig. 11). In one case, in an individual aged about 10 (grave 60/11), an active form was found on the right orbital roof. In individuals with traces of cribra orbitalia, traces of cribra femoris or humeral cribra have also been observed.

When it comes to enamel hypoplasia, traces were observed in every individual, except in the case where individual teeth were conserved. It was recorded in 15 individuals $(12.8 \%)$ and occurs mostly on the central incisors, in the form of lines on the surface of dental crowns. In the examined sample, traces of enamel hypoplasia do not correlate with previously mentioned types of porosity on skeletal remains. In contrast to linear enamel hypoplasia, which was noticed in the largest percentage (Chart 5) in adults, traces of porosity such as cribra orbitalia, cribra femoris and humeral cribra were found predominantly in children (Chart 4). 


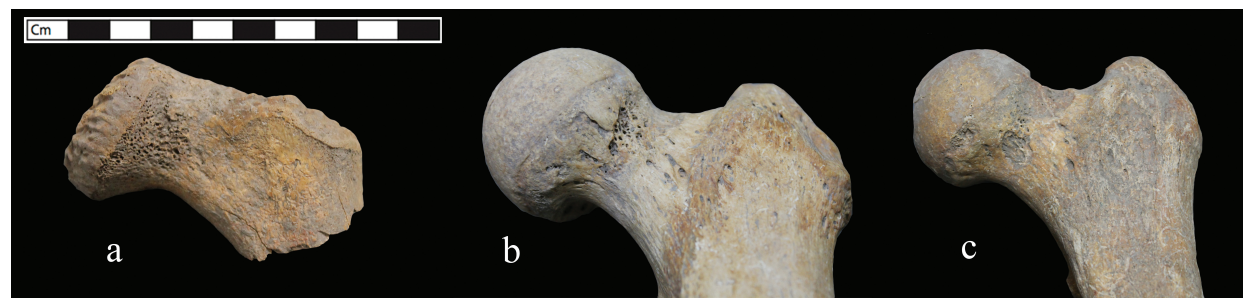

Fig. 10. Evidences of cribra femoris: a) grave 60/11, b) grave 01/04, c) grave 61/11 (Photo by V. Nikolić, edited by I. Mikašinović)

Сл. 10. Трагови cribra femoris: а) гроб 60/11, б) гроб 01/04, ц) гроб 61/11 (Фотографисала В. Николић, обрадио И. Микашиновић)

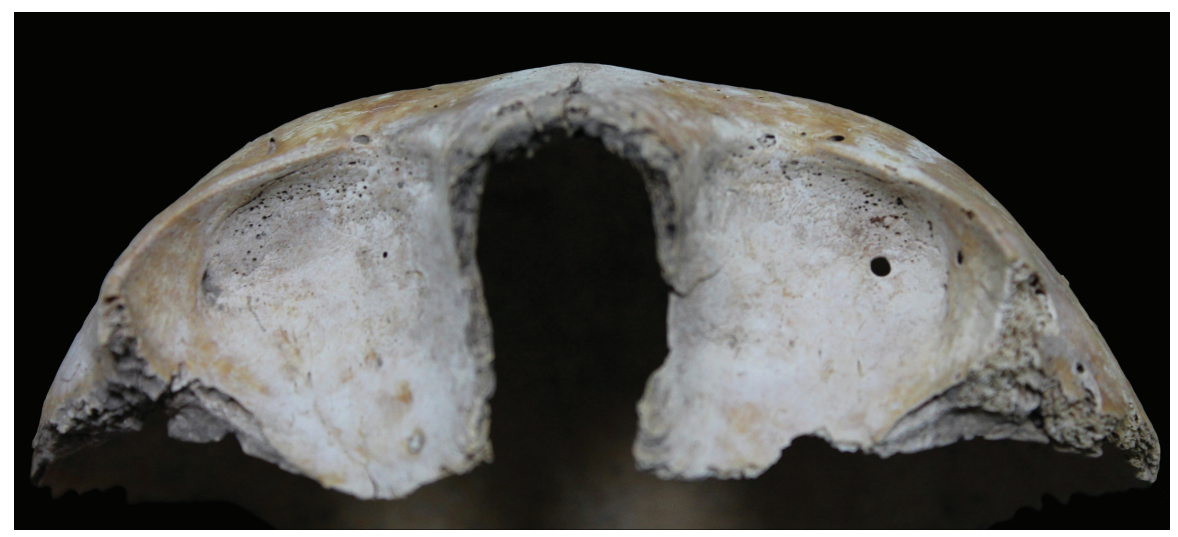

Fig. 11. Evidences of cribra orbitalia: grave 03/04

(Photo by V. Nikolić, edited by I. Mikašinović)

Сл. 11. Трагови cribra orbitalia: гроб 03/04

(Фотографисала В. Николић, обрадио И. Микашиновић)

The analysis of enthesal changes was partially difficult due to poor or incomplete preservation of skeletal remains, especially at the level of observed entheses. Consequently, a more precise reconstruction of work ability and activity patterns by sex and age was difficult or almost impossible. Based on the obtained data, it can be concluded that certain muscle attachments, mostly on the upper and to a lesser extent on the lower extremities, were significantly changed. Taking into consideration the overall state of development of entheses, it can be noticed that the muscle attachments $m$. pectoralis major, $m$. deltoideus (on the upper extremities), m. gluteus maximus, $m$. adductor magnus, $m$. soleus and m. triceps sural (on the lower extremities) are more pronounced than others. In two cases (grave 34/11 and 61/11), enthesopathy of the $m$. pectoralis major was recorded. The analysis of enthesal changes according to the sex and age showed that the muscle attachments are more developed in female than male individuals and in older age. 


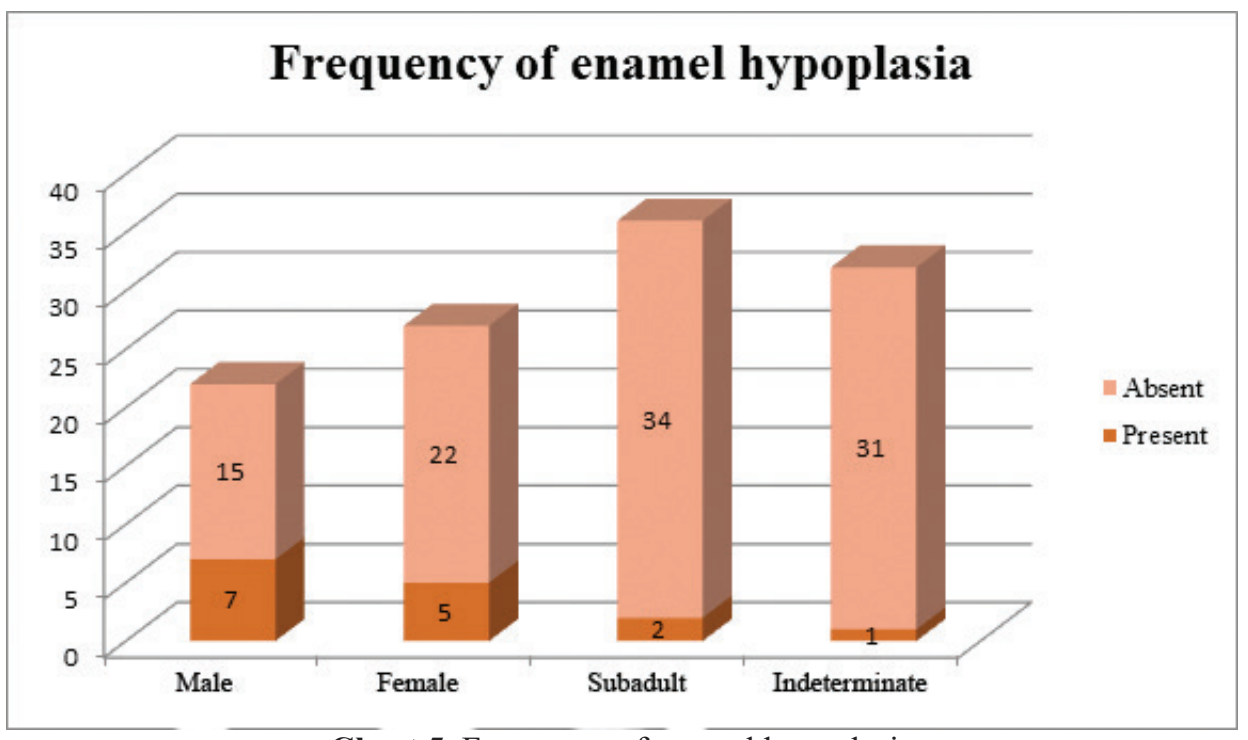

Chart 5. Frequency of enamel hypoplasia

Графикон 5. Учесталост хипоплазије зубне глеђи

\section{Discussion}

As previously mentioned, the degree of preservation of the osteological material is very poor, primarily because of the use of the same burial space for several generations, and therefore there is a dislocation of skeletal parts and mixing of materials. For these reasons, two or more individuals were often documented in graves, but in most cases solely in the form of loose bones. However, based on the data provided by the bones, one can notice a large degree of uniformity according to the sex, but also a high percentage of undetermined sex, which can be seen on other medieval sites in Serbia dated into the same period (Trgovište - Church 1, Deževo, graveyard associated with the Mileševa monastery, monastery church in Žiča and the Church of St. Resurrection in Čačak) (Djuric - Srejić, Roberts, 2001). If we take into consideration the total number of individuals, a relatively high percentage of children is noticeable, almost a third of the total sample. By comparing these results with other necropoles from the same period, we can see that the percentage of children in Vinča is slightly higher than those from the surrounding area, where they are present in about $15-25 \%$ or around a fifth of the sample size (Novak, Bedić, 2011; Šlaus et al., 2011; Novak et al., 2012).

The disparity of average life span between the sexes is not significant. Based on the data, we can see that the average life span for females was about 39 years, while for males it was about 34 . If we compare this data to the ones from the surrounding area, from the same period, we can see that the average life span 
does not significantly differ. Furthermore, the results from several medieval sites in Croatia show that the average life span for males was from 36 to 41 years and for females 38-40 years (Novak, Bedić, 2011; Šlaus et al., 2011; Novak et al., 2012). Considering this, the average female lifespan of about 39 years as well as the high percentage of child individuals could have been the consequence of some social instability as well as inadequate and unfavourable living conditions. In these conditions, women and children become vulnerable groups, which can lead to inadequate care during and after pregnancy and childbirth. As such, these individuals are more exposed to infections and risk of death increases (Bound et al., 1956; Rodgers et al., 2005; Scraton, 2006; Bayon, Berhan, 2012; Gaither, 2012; Lehtonen et al., 2017; Martin, Tegtmeyer, 2017; Banerjee, 2018). For now, it is unclear why the life span of the male population was shorter, considering that we are observing a rural population, not prone to conflicts, as is attested to by the absence of any kind of bone trauma.

On the other hand, the part of researched medieval population examined at this time shows a high percentage of pathological changes, i.e. most individuals suffered from some pathological condition, a high percentage of which are degenerative in nature. If we observe the frequency of these pathological conditions between the sexes, we can see that a slightly higher percentage of them occur in adult females, which may have been a consequence of the lifestyle. More precisely, after taking into consideration that the population was of a rural character and that their main activities were related to household care, child care, as well as agriculture and animal husbandry, it is important to note that this required an exceptional engagement of females, as evidenced by the developed muscle attachments on the bones of the shoulders ( $m$. subscapularis, $\mathrm{mm}$. supraspinatus $i$ infraspinatus, $m$. pectoralis major, $m$. deltoideus). However, the results of antopological analyses from medieval necropoles in Serbia (Trgovište - Church 1, Deževo, graveyard associated with the Mileševa monastery, monastery church in Žiča and the Church of St. Resurrection in Čačak) from the same period show that infectious diseases were more dominant, especially in the younger population, which is due to the characteristics of pre-antibiotic era, unhygienic environment, and unhealthy living habits (Djurić et al., 2010). Furthermore, the male population (2.3\%) was more impacted by infectious diseases than the female (0.6\%) (Djurić-Srejić, Roberts, 2001).

The occurrence of trauma is sporadic and occurring in only three cases. Two of them probably occurred while performing everyday activities, as a result of falling on an outstretched fist, while the third was inflicted by a sharp tool or weapon (Lovell, 1997; Resnick, Kransdorf, 2005; Waldron, 2009). Based on the small number of recorded injuries, it can be assumed that the examined part of the 
medieval society had a relatively peaceful life, without traces of violence. On the other hand, judging by the data from other medieval sites in Serbia, we can see that the percentage of traumas is statistically significant, meaning that other than infectious and dental diseases, traumas represent the most common pathological finding, especially in adult individuals (Djurić-Srejić, Roberts, 2001). Most of these traumas are the result of everyday activities in medieval societies, which matches the results from Vinča - Belo Brdo.

The analysis of the dental material and alveolar diseases showed a low percentage of carious lesions (in $21.2 \%$ or in 24 individuals) and periapical processes (in only 5 individuals). The low incidence of caries and alveolar diseases can be explained by the type of everyday diet. Communities whose diet is based on hunting and consuming foods rich in proteins, such as meat and fish, leads to a lower frequency of these pathological changes because such a diet contains significantly less carbohydrates and increases the $\mathrm{pH}$ value of saliva that absorbs them and thus stays shorter in the mouth, reducing the possibility of bacterial accumulation and formation of pathological changes (Larsen et al., 1991; Hillson, 2005; Šlaus, 2006; Novak et al., 2012; Šlaus et al., 2012). However, the analyses of cranial skeletons from the same necropolis, performed in 2019, show a significantly different picture. Based on the results from these research activities, a high percentage of caries can be seen (on 43 skulls) (Марковић, Јовановић, 2019) and, therefore, this is either a part of the population that took more care of oral hygiene and nutrition, which is unlikely, or it is just a problem related to the poor level of preservation of the dental material. Furthermore, it should be noted that out of over 700 graves excavated in the campaign 1978-1983, only 50 skulls were saved and analysed. The criteria for selection of these skulls are not known, whether it was a random sample or if only the ones with pathological changes were picked.

The examination of bioindicators of subadult stress, such as cribra orbitalia, cribra femoris, humeral cribra and enamel hypoplasia, showed an almost identical situation. In the analysed sample, the percentage of present bioindicator of stress is extremely low (cribra orbitalia $-10.3 \%$ cribra femoris $-17.9 \%$, humeral cribra $-1.7 \%$, enamel hypoplasia $-12.8 \%$ ). When it comes to porotic changes on the orbital roof or necks of the humerus and femur, a higher frequency of stressful events was observed in children, aged 3-5, as well as in women aged 28-35, which is not surprising given that they represent vulnerable groups (Bound et al., 1956; Scraton, 2006; Bayon, Berhan, 2012; Gaither, 2012; Lehtonen et al., 2017; Martin, Tegtmeyer, 2017; Banerjee, 2018).

In the mentioned categories, the need for nutrients is higher; both due to the development of children (Lehtonen et al., 2017; Banerjee, 2018), and to the 
same need in pregnant and breastfeeding women (Dietrich et al., 2013; Weldearegami et al., 2015; Banerjee, 2018). On the other hand, enamel hypoplasia occurs in a higher percentage in adult individuals and is often not correlated with traces of the above-mentioned porosities, which indicates that these individuals also had phases of anaemic stress (Goodman, 1991; Ortner, 2003; Brickley, Ives, 2008), which was overcome in the subadult age. Judging by data provided by indicators of subadult stress, it is assumed, despite the small number of all separate indicators, if cumulatively observed, that they may be the result of an unbalanced and monotonous diet, with insufficient nutrients (Lukacs, 1989; Ortner, 2003; Brickley, Ives, 2008).

Comparing the obtained results with those from a sample of 50 skulls from the same necropolis, both cribra orbitalia (about $85 \%$ ) and enamel hypoplasia (about 70\%) (Марковић, Јовановић, 2019) are represented in a significantly higher percentage than is the case in individuals analysed in this research. Such data shows a significant disparity, which may indicate the existence of a part of the medieval community that lived in relatively better conditions and cared more about vulnerable groups. Alternatively, this may simply be a consequence of the poor preservation of the skeletal remains.

If the results of the performed bioanthropological analysis from the medieval necropolis Vinča - Belo Brdo are compared with those from the same period in Serbia, as well as in other countries in the region and further afield, it can be seen that in most medieval necropoles $\left(12^{\text {th }}-14^{\text {th }}\right.$ century) there is a higher percentage of bioindicators of subadult stress and infectious diseases, as well as alveolar diseases, which would indicate poor sanitation, poor oral hygiene and diet rich in carbohydrates (Novak and Šlaus, 2007; Djurić et al., 2008; 2010; Novak et al., 2010; 2012; Novak, 2011; Marcu Istrate et al., 2015). An exception can be found in the skeletal remains from the medieval necropolis in Nin and next to the church of St. Franjo in Opatovina, Zagreb, where, as the authors state, the reason for the low prevalence of dental pathology and the reduced frequency of cribrous lesions is a higher social status (Šlaus et al., 2007; Novak et al., 2012).

\section{Conclusion}

Despite the poor preservation of skeletal remains, and the consequent impossibility to fully examine the sample, the obtained results of the bioanthropological analysis of skeletal remains from the medieval necropolis of Vinča - Belo Brdo indicate an almost uniform distribution by sex, with no significant deviation from the average age between male and female individuals. The percentage of 
pathological changes is relatively high, which could be a result of the bad living conditions of the population, as well as inadequate care of the sick. However, this conclusion should be taken with caution due to the small sample and the assumed type of settlement in which they lived. Considering that the necropolis in Vinča - Belo Brdo has not been explored in its entirety, i.e. only one part of it has been excavated, and it has revealed about 1,000 human skeletons so far, it speaks of a large buried population, and thus overcrowding, which can be manifested on skeletal remains. Comparison of these results with others from various medieval necropoles in Serbia and in the region, from the period from the $12^{\text {th }}-14^{\text {th }}$ century, is difficult because of the limited amount of published analyses of human osteological material.

\section{REFERENCES}

Angel, J.L., 1966. Porotic hyperostosis, anemias, malarias and marshes in the prehistoric Eastern Mediterranean. Science, 153/1966: 760-763.

Banerjee, S., 2018. Major Determinants of Infant Mortality: District-level Evidences from Odisha, Journal of Health Managment 20(3): 1-18.

Bass, W.M., 1995, Human Osteology. A Laboratory and Field Manual of the Human. Bayon, G., Berhan, Y., 2012. Perinatal mortality and associated risk factors: a case control study, Ethiopian Journal of Health Science, Vol. 22, No.3, pp.153-162.

Blažić, S., 1999a. Ostaci životinjskih kostiju sa lokaliteta Ras - Gradina, u: M. Popović, Tvrđava Ras, 439-445. Beograd: Arheološki institut.

Блажић, С., 1999б. Остаци животињских костију са локалитета Рад - Градина, Новопазарски зборник 23: 29-53.

Bound, J.P., Butter, N.R., Spector, W.G., 1956. Classification and causes of perinatal mortality. British Medical Journal, 1191-1196.

Brickley, M., Ives, R., 2008. The Bioarchaeology of Metabolic Bone Disease. San Diego: Elsevier Academic Press.

Brickley, M.B., 2018. Cribra orbitalia and porotic hyperostosis: A biological approach to diagnosis, Americal Journal of Physical Anthropology, 1-7.

Brothwell, D. R., 1981. Digging up Bones. London: British Museum (Natural History); Oxford Press.

Buikstra, J. E. and Ubelaker, D. H., 1994. Standards for Data Collection from Human Skeletal Remains. Arkansas: Arkansas Archaeological Survey Report No. 44.

Buikstra, J. E., 2019. Ortner's Identification of Pathological Conditions in Human Skeletal Remains. San Diego: Elsevier Academic Press

Булатовић, J., Марковић, Н., 2013. Остаци животиња из средњовековног утврђења Градина-Трешњевица код Ивањице. Зборник Народног музеја XXI-1: 291-298. 
Булатовић, J., Марковић, Н., 2019. Рудник 2009-2013: резултати археозоолошких истраживања, у Рудник 1: Истраживања средюовековних налазишта (2009-2013), ур. Д. Радичевић и А. Цицовић. Горњи Милановац: Музеј рудничко-таковског краја. 119-129.

Dietrich, C.M., Felice, J.P., O'Sullivan, E., Rasmussen, K.M., 2013. Breastfeeding and health outcomes for the mother - infant dyad. Pediatric Clinics of North America 60 (1): 31-48. Djurić-Srejić, M., Roberts, C., 2001. Palaeopathological Evidence of Infectious Disease in Skeletal Populations from Later Medieval Serbia, International Journal of Osteoarchaeology 11: 311-320.

Djurić, M.P., Roberts, C.A., Rakočević, Z.B., Djonić, D.D., Lešić, A.R., 2006. Fractures in Late Medieval Skeletal Populations From Serbia. American Journal of Physical Anthropology 130: 167-178.

Djurić, M., Milovanović, P., Janović, A., Drašković, M., Đukić, K. i Milenković, P., 2008. Porotic lesions in immature skeletons from Stara Torina, late medieval Serbia, International Journals of Osteoarchaeology 18: 458-475.

Djurić, M., Janović, A., Milovanović, P., Đukić, K., Milenković, P., Drašković, M., Roksandić, M., 2010. Adolescent health in medieval Serbia: signs of infectious diseases and risk of trauma. HOMO - Journal of Comparative Human Biology 61: 130-149.

Đukić, K., Milovanović, P., Hahn, M., Busse, B., Amling, M., Djurić, M., 2015. Bone Microarchitecture at Muscle Attachment Sites: The Relationship Between Macroscopic Scores of Entheses and Their Cortical and Trabecular Microstructural Design, American Journal of Physical Anthropology 157: 81-93

Đukić, K., 2016. Bone macromorphology at muscle attachment sites: its relationship with the microarchitecture of the underlying bone and possible implications for the reconstruction of habitual physical activities of past populations. Doctoral Dissertation. Belgrade. School of Medicine, University of Belgrade.

Ferembach, D., Schwidetzky, I., Stloukal, M., 1980. Recommendations for age and sex diagnosis of skeletons. Journal of Human Evolution 7: 523-525.

Фидановски, С., Зечевић, Е., 2015. Два средњовековна гробља у Ритопеку код Београда, Гласник Српског археолошког друштва 31: 187-220.

Gaither, C., 2012. Cultural Conflict and the Impact on Non-adults at Puruchuco-huaquerones in Peru: The Case for Refinement of the Methods Used to Analyze Violence Against Children in the Archeological Record. International Journal of Paleopathology, 2, 69-77.

Goodman, A.H., 1991. Stress, adaptation, and enamel developmental defects. In: Ortner, D., J., Aufderheide, A.C. (eds.): Human Paleopathology. Current Syntheses and Future Options, Smithsonian Institution Press: 280-287.

Hillson, S., 2005. Dental Anthropology. Cambridge University Press, Cambridge.

Işcan, M. Y., Loth, S. R and Wright, R. K., 1984. Metamorphosis at the sternal rib end: A new method to estimate age at death in white males. American Journal of Physical Anthropology 65: 147-156.

Işcan, M. Y., Loth, S. R. and Wright, R. K., 1985. Age estimation from the rib by phase analysis: white females. Journal of Forensic Science 30: 853-863. 
Калић, Ј., 1995. Београд у средњем веку, у: Историја Београда, ур. 3. Антонић, 50-87. Београд: Балканолошки институт САНУ; Издавачка кућа Драганић.

Larsen C.S., Shavit, R., Griffin, M.C., 1991. Dental caries evidence for dietary change: An archaeological context, in: Kelley, M.A., Larsen, C.S. (ed.): Advances in Dental Anthropology, New York, 179-202.

Lehtonen, L., Gimeno, A., Parra - Llorca, A., Vento, M., 2017. Early neonatal death: A challenge worldwide, Seminars in Fetal \& Neonatal Medicine XXX (2017): 1-8.

Lovell, N.C., 1997. Trauma Analysis in Paleopathology. Yearbook of Physical Anthropology 40: 139-170.

Lukacs, J.R., 1989. Dental paleopathology: methods for reconstructing dietary patterns. U: Reconstruction of Life from the Skeleton (ur. Iscan M. Y., Kennedy K. A. R.). New York: 261-286.

Marcu Istrate, D., Constantinescu, M., Soficaru, A., 2015. The medieval cemetery from Sibiu (Hermannstadt) Huet Square.Tübinger Forschungen zur historischen Archäologie Band 6.

Maresh, M.M., 1955. Linear growth of the long bones of extremities from infancy through adolescence. American Journal of Diseases of Children 89: 725-742.

Maresh, M.M., 1970. Measurements from Roentgenograms. In R. W. McCammon (Ed.), Human Growth and Development. Springfield, IL: C.C. Thomas, 157-200.

Марјановић-Вујовић, Г., 1984. Средњовековна Винча, у: Винча у праисторији и средњем веку, ур. Д. Срејовић (Галерији САНУ 50), 85-99. Београд: Српска академија наука и уметности.

Марковић, Ј., Јовановић, Ј., 2019. Здравствени статус и исхрана индивидуа сахрањених на средњовековној некрополи Винча - Бело брдо, Гласник Српског археолошког друитва 35: 123-151.

Marković, N., Bulatović, J., 2013. Ploughing in Medieval Times on the Territory of Present-Day Serbia. Archeometriai Mühely 2013/X./3: 225-230.

Martin, D.L., \& Tegtmeyer, C. (Eds.). 2017. Bioarchaeology of women and children in times of war: Case studies from the Americas. New York: Springer.

Mikić, I., 2009. Epigenetske varijacije na srednjovekovnim lobanjama iz Vinče-identifikacija i interpretacija. Master rad. Filozofski fakultet, Univerzitet u Beogradu.

Mikić, Ž., 1978. O antropološkoj metodologiji terenske obrade skeletnih nalaza. Godišnjak Centra za balkanološka ispitivanja Akamedija nauka i umjetnosti Bosne i Hercegovine 16/14, 3-44.

Микић, Ж., 1988. Антрополошка структура становништва Србије. Београд: Стручна књига.

Милошевић, Г., 1997. Становање у средњовековној Србији. Београд: Археолошки институт, Београд.

Mladenović, T., 2017. Faunal remains from fortified medieval castle at the KulinaSolotuša site (Western Serbia), in: Archaeology and Science 12 (2016), Center for New Technology Institute of Archaeology Belgrade. Belgrade, 115-147. 
Novak, M., Šlaus, M., 2007. Učestalost i distribucija cribra orbitaliae u kasnosrednjovekovnoj populaciji iz Dugopolja. Starohrvatska prosvjeta 34, 451-475.

Novak, M., Šlaus, M., Vyroubal, V., Bedić, Ž., 2010. Dental pathologies in rural medieval populations from continental Croatia. Anthropologiai Közlemények 51: 11-21.

Novak, M., 2011. Bioarchaeological Analysis of the Human Skeletal Remains from the Late Mediaeval Cemetery of Koprivno, Southern Croatia. Bulletin of the International Association for Paleodontology. 5(1): 13-23.

Novak, M., Bedić, Ž., 2011. Bioarheološke karakteristike srednjovjekovne populacije s nalazišta Suhopolje-Kliškovac, in: Suhopolje-Kliškovac: Od mjestopisa do arheološke spoznaje, Tomičić Ž., Jelinčić K., (eds.), Zagreb, 165-174.

Novak M., Martinčić, O., Strinović, D., Šlaus, M., 2012. Skeletal and dental indicators of health in the late mediaeval (12-15th century) population from Nin, southern Croatia. HOMO - Journal of Comparative Human Biology 63: 435-450.

Ortner, D.J., 2003. Identification of Pathological Conditions in Human Skeletal Remains. San Diego: Elsevier Academic Press.

Пенезић, К., Радичевић, Д., Булатовић, Ј., Тасић, Н., 2020. Први резултати заштитних археолошких истраживања на Белом брду у Винчи 2019. године. Гласник Српског археолошког друштва 36: 261-281.

Pfeiffer, S., 1991. Estimation of age at death. U Pfiffer, S. - S.R. Williamson (ed.). An investigation of a military cemetery from the war of 1812. Toronto: 167-175.

Resnick, D., Kransdorf, M.J., 2005. Bone and Joint Imaging. Third edition. San Diego: Elsevier Academic Press.

Rinaldo, N., Zedda, N., Bramanti, B., Rosa, I., Gualdi-Russo, E., 2019. How reliable is the assessment of Porotic Hyperostosis and Cribra Orbitalia in skeletal human remains? A methodological approach for quantitative verification by means of a new evaluation form, Archaeological and Anthropological Sciences 11: 3549-3559.

Rogers, R.G., Hummer, R. A., Krueger, P. M., 2005. Chapter 10 - Adult Mortality, In Poston D.L.Jr., Micklin, M., eds., Handbook of Population, First Edition, Springer, pp. 283-309.

Scheuer, L. and Black, S., 2004. Developmental Juvenile Osteology. London: Elsevier Academic Press.

Schultz, M., 2001. Paleohistopathology of bone: a new approach to the study of ancient diseases. Yearbook of Physical Anthropology 44: 106-147.

Scraton, P., 2006. Children, violence and transition. Criminal Justice Matters, 66(1), 28-29.

Stuart-Macadam, P., 1985. Porotic hyperostosis: representative of a childhood condition. American Journal of Physical Anthropology 66/1985: 391-398.

Stuart-Macadam, P., 1989. Porotic Hyperostosis: Relationship Between Orbital and Vault Lesions. American Journal of Physical Anthropology 80: 187-193.

Stuart-Macadam, P., 1992. Porotic hyperostosis: a new perspective. American Journal of Physical Anthropology 87/1992: 39-47. 
Suchey J. M. and Brooks, S., 1990. Skeletal age determination based on the os pubis: A comparison of the Acsádi-Nemeskéri and Suchey-Brooks methods. Human Evolution 5: 227-238.

Šlaus, M., 2006. Bioarheologija: demografija, zdravlje, traume i prehrana starohrvatskih populacija, Školska knjiga, Zagreb

Šlaus, M., Novak, M., Bedić, Ž., Vyroubal, V., 2007. Antropološka analiza kasnosrednjovekovnog groblja kraj crkve sv. Franje na Opatovini u Zagrebu. Arheološki radovi $i$ rasprave 15: 211-247.

Šlaus, M., Novak, M., Vyroubal, V., Bedić, Ž., 2011. Antropološka analiza ljudskog osteološkog materijala sa nalazišta Stranče - Gorica, in: Stranče - Vinodol, starohrvatsko groblje na Gorici, Cetinić, Ž., (ed.). Pomorski i povijesni muzej Hrvatskog primorja Rijeka, Bibliotela Monografije i katalozi, svezak 26: 303-343.

Šlaus M., Novak, M., Bedić, Ž., Vyroubal, V., 2012. Antropološka analiza starohrvatskog koštanog uzorka s tumula Jokina glavica. Sveučilište u Zadru odjel za arheologiju. Zadar. 91-102.

Tасић, Н., 2008. Винча - метропола касног неолита, у: Винча - праисторијска метропола: истраживања 1908-2008, ур. Д. Николић (Галерија САНУ 114), Београд: Филозофски факултет Универзитета у Београду; Народни музеј у Београду; Музеј града Београда; Српска академија наука и уметности.

Trotter, M. and Gleser, G. C., 1958. A re-evaluation of estimation of stature based on measurements of stature taken during life and long bones after death. American Journal of Physical Anthropology 16: 79-123.

Ubelaker, D. H., 1984. Human skeletal remains: excavation, analysis, interpretation. Washington: Taraxacum.

Waldron, T., 2009. Paleopathology. Cambridge University Press: 138-168.

Walker, P.L., Bathurst, R.R., Richman, R., Gjerdrum, T., Andrushko, V.A., 2009. The Causes of Porotic Hyperostosis and Cribra Orbitalia: A Reappraisal of the Iron-Deficiency-Anemia Hypothesis, American Journal of Physical Anthropology 139: 109-125.

Weldearegawi, B., Melaku, Y. A., Abera, S. F., Ashebir, Y., Haile, F., Mulugeta, A., Eshetu, F., and Spigt, M., 2015. Infant mortality and causes of infant deaths in rural Ethiopia: a population-based cohort of 3684 births, BMC Public Health 15: 770.

Workshop of European Anthropologists, 1980. Recommendations for age and sex diagnoses of skeletons. Journal of Human Evolution 9(7): 518-549.

Zarina, G., Sholts, S. B., Tichinin, A., Rudovica, V., Viksna, A., Engizere, A., Muižnieks, V., Bartelink, E.J, Wärmländer, S.K.T.S., 2016. Cribra orbitalia as a potential indicator of childhood stress: Evidence from paleopathology, stable $\mathrm{C}, \mathrm{N}$, and $\mathrm{O}$ isotopes, and trace element concentrations in children from a 17th-18th century cemetery in Jekabpils, Latvia. Journal of Trace Elements in Medicine and Biology 38: 131-137. 


\title{
Веда Николић
}

Лабораторија за Антропологију, Медицински факултет, Универзитет у Београду

\section{Ксенија Ђукић}

Лабораторија за Антропологију, Медицински факултет, Универзитет у Београду

\section{Кристина Пенезић}

Институт Биосенс, Универзитет у Новом Саду

\section{БИОАНТРОПОЛОШКА АНАЛИЗА СРЕДЊОВЕКОВНЕ ПОПУЛАЦИЈЕ СА ЛОКАЛИТЕТА ВИНЧА - БЕЛО БРДО: ПРЕЛИМИНАРНИ РЕЗУЛТАТИ}

\begin{abstract}
Кључне речи: Винча - Бело брдо, средњовековна некропола, палеодемографске и палеопатолошке анализе, денталне болести, субадултни стрес, ентезалне промене
\end{abstract}

У раду су представљени прелиминарни резултати биоантрополошке анализе хуманог остеолошког материјала са средњовековне некрополе Винча - Бело брдо, прелиминарно датоване 12-14. века, на основу спорадичних гробних прилога (Пенезић и др., 2020).

Након вишедеценијског прекида, истраживања средњовековне некрополе настављена су 2004, 2005, 2011, а потом и 2019. и 2020. године. Истраживања су пре свега била заштитног карактера и обављена су у делу локалитета који је био непосредно угрожен клизиштем и неповратним губитком драгоцених података.

Биоантрополошка анализа је обављена у Лабораторији за Антропологију Медицинског факултета у Београду. Анализом је обухваћен узорак од укупно 117 индивидуа из 68 гробних целина истражених током кампања 2004, 2005. и 2011. године.

Након обављене антрополошке анализе констатовано је да се у готово свим гробовима поред примарно сахрањене индивидуе налазе и појединачне кости или делови скелета других индивидуа, што додатно потврђује да је некропола била коришћена у дужем периоду, за више генерација. Стога је дошло и до мешања материјала и делимичне његове девастације. Из истих разлога не изненађује ни чињеница да је проценат степена очуваности скелетног материјала претежно испод 50 \% (чак 73,5 \%) (Графикон 1). 
Анализа дистрибуције по полу и старости је показала да је од 117 опсервираних индивидуа, 27 било женског пола, 22 мушког пола, а 36 припада дечјим индивидуама, док код укупно 32 индивидуе није било могуће прецизно утврдити пол, због лоше очуваности скелетних остатака (Графикон 2). Палеодемографска анализа је показала готово уједначену дистрибуцију и по старости, када је реч о одраслим индивидуама. Просечна старост одраслих индивидуа је износила око 34 године (за мушки пол), око 39 година (за женски пол) и око 3,2 године (за узраст 0-15 година).

Анализа палеопатолошког стања сахрањене популације показала је изузетно висок проценат забележених патолошких промена (79,5\%) (Графикон 3), класификованих у дегенеративне промене, инфективна обољења, трауме и денталне болести. Поред овога, на испитиваном узорку констатован је релативно низак проценат индикатора субадултног стреса. Међутим, треба имати на уму да је антрополошка анализа донекле била ограничена пре свега лошом очуваношћу скелетног материјала. Исто тако, с обзиром на то да некропола није истражена у целости, и да је овом приликом истражен и обрађен само један мали проценат, опсежније и прецизније закључке нисмо у могућности да донесемо. Ипак, резултати обављене антрополошке анализе нам показују висок проценат дечјих индивидуа, као и готово уједначену дистрибуцију по полу. Такође, висока заступљеност патолошких промена код сахрањених индивидуа указује на неадекватне услове живота и неодговарајућу негу болесних, односно на тешке услове и велику физичку активност са којима се популација свакодневно суочавала. 